\title{
Sunflower cake in diets for lambs: intake, digestibility, nitrogen balance and rumen parameters
}

\section{Torta de girassol em dietas para borregos: consumo, digestibilidade, balanço de nitrogênio e parâmetros ruminais}

\author{
Elizabeth dos Santos Moura ${ }^{1 *}$; Leandro das Dores Ferreira da Silva ${ }^{2}$; \\ Eduardo Lucas Terra Peixoto ${ }^{3}$; Valter Harry Bumbieris Junior ${ }^{2}$; \\ Edson Luis de Azambuja Ribeiro ${ }^{2,4}$; Ivone Yurika Mizubuti²,4; \\ Ana Paula de Souza Fortaleza ${ }^{2}$
}

\begin{abstract}
The present study objective was to determine the intake and digestibility, nitrogen balance and ruminal fermentation parameters in sheep fed diets containing levels of substitution of soybean meal for sunflower cake. The diets consisted of five levels of protein soybean meal $(0,25,50,75$ and $100 \%)$ by sunflower cake. Diets were formulated with $12.6 \% \mathrm{CP}$, respecting the roughage:concentrate ratio of 40:60, as source roughage was used hay Tifton- 85 and as food concentrates used were: corn, soybean meal, sunflower cake and premix mineral vitaminic. Five lambs crossbred castrated with average weight of $29.64 \pm 2.94 \mathrm{~kg}$ were used, distributed in latin square $5 \times 5$. There were no differences in intake dry matter (DM), organic matter $(\mathrm{OM})$, crude protein (CP), neutral detergent fiber (NDF) and total digestible nutrients. The intake of ether extract (EE) and non-fiber carbohydrates (NFC) were increased linearly. For intake of total carbohydrates (TC) was observed equation linear in relation to body weight and metabolic weight and quadratic when expressed in $\mathrm{g}_{\text {day }}{ }^{-1}$ with peak in $377.1 \mathrm{~g} \mathrm{~kg}^{-1}$ replacement of soybean meal by sunflower cake. There were no differences in digestibility DM, OM, CP, NDF, NFC and TC. There was a linear increase in the digestibility of ether extract (EE). The intake, feces, urinary and retained nitrogen were not influenced by levels of substitution of soybean meal by sunflower cake in the diets. For the $\mathrm{pH}$ of liquor ruminal there was no difference for the different levels of substitution of soybean meal by sunflower cake. However, ruminal $\mathrm{pH}$ differed with respect to collection time for all experimental diets. There was no effect on diets and sampling time for concentration of $\mathrm{NH}_{3}-\mathrm{N}$. It was concluded that the sunflower cake can be used as an alternative food to replace soybean meal up to $100 \%$ in concentrate mixture unless there are changes in the rumen parameters, balance of nitrogen, intake and nutrient digestibility.
\end{abstract}

Key words: Co-products, oilseed, ruminants

\section{Resumo}

Objetivou-se com este estudo, determinar o consumo e digestibilidade dos componentes nutritivos, balanço de nitrogênio e os parâmetros de fermentação ruminal em borregos alimentados com rações

\footnotetext{
${ }^{1}$ Discente de Doutorado em Ciência Animal, Universidade Estadual de Londrina, UEL, Londrina, PR, Brasil. E-mail: esmoura@, zootecnista.com.br

2 Profs. Drs., Dept ${ }^{\mathrm{o}}$ de Zootecnia, UEL, Londrina, PR, Brasil.E-mail: leandro@uel.br; jrbumbieris@uel.br; elar@uel.br; mizubuti@ uel.br; anapaula_fortaleza@uel.br

3 Prof. Dr., Faculdade Ciências Agrárias, IEDAR, Universidade Federal do Sul e Sudeste do Pará, UNIFESSPA, Marabá, PA, Brasil. E-mail: eltpeixoto@unifesspa.edu.br

${ }^{4}$ Pesquisadores CNPq.

* Author for correpondence
} 
contendo diferentes teores de torta de girassol em substituição ao farelo de soja. Os tratamentos consistiram em cinco níveis de substituição da proteína do farelo de soja (0;25;50; 75 e $\left.100 \mathrm{~g} \mathrm{~kg}^{-1} \mathrm{MS}\right)$ pela torta de girassol. As rações foram formuladas com $12,6 \%$ PB respeitando-se uma relação volumoso:concentrado de 40:60, tendo como fonte volumosa o feno de Tifton-85 e ração suplementar formuladas com milho, farelo de soja, torta de girassol, mistura mineral e vitamínica. Foram utilizados cinco borregos sem raça definida, castrados, com peso vivo médio de 29,64 $\pm 2,94 \mathrm{~kg}$, distribuídos em quadrado latino 5 x 5 . Não houve diferenças nos consumos de matéria seca (MS), matéria orgânica (MO), proteína bruta (PB), fibra em detergente neutro (FDN) e nutrientes digestíveis totais (NDT). O consumo de extrato etéreo (EE) e carboidratos não fibrosos (CNF) apresentaram efeito linear crescente independente da forma expressa. Para o consumo de carboidratos totais (CT) foi verificado comportamento linear em relação ao peso corporal e peso metabólico e quadrático quando expresso em $\mathrm{g} \mathrm{dia}^{-1}$ tendo como ponto máximo em $377,1 \mathrm{~g} \mathrm{~kg}^{-1}$ de substituição de farelo de soja por torta de girassol. Não foram observadas diferenças nos coeficientes de digestibilidade da MS, MO, PB, FDN, CT e CNF. Houve aumento linear no coeficiente de digestibilidade do EE. O consumo de nitrogênio, os teores de nitrogênio fecais, urinários e retidos não foram influenciados pelos teores de substituição do farelo de soja por torta de girassol nas dietas. $\mathrm{O}$ pH do líquido ruminal não apresentou diferença para os diferentes teores de substituição do farelo de soja por torta de girassol. Contudo, o pH do líquido ruminal diferiu em relação ao tempo de coleta, para todas as rações experimentais. Não houve efeito no tempo de coletas para concentração de $\mathrm{N}_{-} \mathrm{NH}_{3}$. Conclui-se que a torta de girassol pode ser utilizada como alimento alternativo na substituição do farelo de soja em até $100 \%$ sem que ocorram alterações nos parâmetros ruminais, balanço de nitrogênio e consumo e digestibilidade dos componentes nutritivos estudados.

Palavras-chave: Coproduto, oleaginosa, ruminantes

\section{Introduction}

From among the byproducts with potential use in ruminant feed, we highlight those arising of biodiesel production as the cakes and meal that have characteristics nutritional proper for inclusion in ruminant feeds (ABDALLA et al., 2008; LAGE et al., 2010).

The sunflower cake is an excellent source of nutrients for lambs because is composed by oil rich in polyunsaturated fatty acids $(65.3 \%)$, crude protein content is about 22-33\% (NAGALAKSHMI et al., 2011; PEREIRA et al., 2011a), and high dry matter digestibility (65\%) (BERAN et al., 2007). As all vegetable oils, sunflower oil essentially consists of triglycerides (98 to 99\%), low linolenic acid content and high linoleic acid content, the changes that occur in the concentration and composition of fatty acids arise from the varieties, climate change during its cultivation and degree of maturity (PEREZ; CARELLI; CRAPISTE, 2004).

Cakes result of mechanical crushing of the grain in the shell without cooking and use of solvent present have ether extract content (around 15\% DM).
However, there is much variation in the chemical composition of these byproducts, resulting mainly from different origins and sunflower varieties, the press model, the setting used (GOES et al., 2010).

However, only the chemical composition is not enough to determine the use of a byproduct in animal feed, is necessary to evaluate nutritional characteristics as intake, digestibility, ruminal metabolism and nitrogen balance. Other aspects are also important in determining the use of the byproduct of them stand out from the presence of anti-nutritional factors, palatability and acceptability by the animal and availability.

By means of the above, aimed to evaluate the use of sunflower cake in rations for lambs, replacing soybean meal, through the intake and digestibility of the nutritional components, nitrogen balance and ruminal metabolism.

\section{Material and Methods}

The experiment was carried on the premises of the animal production sector at the Farm School 
belonging to the Londrina State University (UEL).

Five lambs undefined breed, castrated, with average live weight of $29.64 \pm 2.94 \mathrm{~kg}$ were housed in cages with leaky floor with $1.80 \mathrm{~m}^{2}$ of floor area with individual feeders and waterers for the metabolism trial. For total feces collection, collector bags were used. The animals were weighed at the beginning and end of each evaluation period for adjustment of diets. Each trial period lasted 15 days, the first ten days were for diet adaptation. Experimental animals were submitted to the preexperimental period (approximately 15 days) for adaptation to the metabolism cage, routine handling and feeding. Diets were given as a whole mixture twice a day at 7:30 a.m. and 4:30 p.m. to minimize feed loss by animals.
Were evaluated a control diet (without sunflower cake) and four levels 25; 50; 75 and 100\% soybean meal replacement by sunflower cake. The experimental periods were 15 days duration, with 10 days of adaptation diets with five days of sample collection carried out in the period between the 11th and 15th day. Experimental animals were submitted to the pre-experimental period (approximately 15 days) for adaptation to the metabolism cage, routine handling and feeding.

All diets were kept at a forage to concentrate ratio of 40:60, where the source of forage was hay Tifton-85 (Cynodon spp) and the concentrate ration sources were, corn, soybean meal, sunflower cake, vitamin and mineral mixture (Table 1). The rations were given as total mixture in order to minimize the selection for the animals.

Table 1. Composition chemical-bromatological average $\left(\mathrm{g} \mathrm{kg}^{-1}\right.$ of dry matter) of the food used in the experiment.

\begin{tabular}{lcccc}
\hline \multicolumn{1}{c}{ Components } & Tifton 85 hay & Ground corn & Soybean meal & Sunflower cake \\
\hline $\mathrm{DM}^{1}\left(\mathrm{~g} \mathrm{~kg}^{-1}\right)$ & 810.34 & 859.63 & 875.68 & 902.89 \\
$\mathrm{OM}^{2}$ & 933.95 & 986.12 & 937.28 & 946.91 \\
$\mathrm{CP}^{3}$ & 80.48 & 95.65 & 502.20 & 264.57 \\
$\mathrm{EE}^{4}$ & 13.53 & 33.74 & 20.28 & 206.62 \\
$\mathrm{NDF}^{5}$ & 731.39 & 275.77 & 221.84 & 302.93 \\
$\mathrm{ADF}^{6}$ & 339.95 & 33.05 & 86.61 & 199.21 \\
$\mathrm{CEL}^{7}$ & 300.71 & 18.78 & 66.29 & 148.84 \\
$\mathrm{LIG}^{8}$ & 315.12 & 24.10 & 71.97 & 156.66 \\
$\mathrm{TC}^{9}$ & 839.94 & 856.72 & 414.80 & 475.72 \\
$\mathrm{NFC}^{10}$ & 108.55 & 580.95 & 192.96 & 172.79 \\
\hline
\end{tabular}

${ }^{1}$ dry matter; ${ }^{2}$ organic matter; ${ }^{3}$ crude protein; ${ }^{4}$ ether extract; ${ }^{5}$ neutral detergent fiber; ${ }^{6}$ acid detergent fiber; ${ }^{7}$ cellulose; ${ }^{8}$ lignin; ${ }^{9}$ total carbohydrates; ${ }^{10}$ non-fiber carbohydrates.

Source: Elaboration of the authors.

The animals were weighed at the beginning and end of each evaluation period for adjustment of diets. Each trial period lasted 15 days, the first ten days were for diet adaptation. Diets were formulated to be isonitrogenous with $127 \mathrm{~g} \mathrm{CP} \mathrm{kg}^{-1}$ dry matter bases (Table 2) and were increased by $10 \%$ to the requirements according to the NRC (2007).
The weighing of food offered and orts was performed daily, and data collected regarding the feeding portions for each animal during each trial period were later analyzed. Offered food and orts, as well as feces and urine, were sampled from the 11 th up to 14 th day of each trial period to determine intake, nutrient digestibility and nitrogen balance. 
Solid samples (supplied diet, orts and feces) were placed in plastic bags, identified, and frozen at a temperature of $-18^{\circ} \mathrm{C}$ immediately after collection. At the end of the experimental period, the samples were defrosted and dried in forced air ovens at a temperature of $55^{\circ} \mathrm{C}$ for 72 hours. Subsequently, they were milled in a Willey-type mill with a sieve of $1 \mathrm{~mm}$.

Chemical composition was identified using the methodology described by AOAC (1990) cited by Mizubuti et al. (2009) for determining the content of dry matter (DM), crude protein (CP), ether extract (EE), ash. Neutral detergent fiber (NDF), acid detergent fiber (ADF) and lignin were determinate by methodology described by Van Soest (1967) whit adaptations proposed by Detmann et al. (2012). Total carbohydrates (TCH) contents were calculated according to the equation proposed by Sniffen, O'Condor and Van Soest (1992): \% $\mathrm{TCH}=$ $1000-(\mathrm{CP}+\mathrm{E}+\mathrm{ash})$. The non fibrous carbohydrate (NFC) content was calculated using the difference between TCH and NDF.

Table 2. Formula and chemical composition of rations for lambs containing inclusion levels of soybean meal by sunflower cake.

\begin{tabular}{lccccc}
\hline \multirow{2}{*}{ Feeds } & \multicolumn{5}{c}{${\text { Levels of sunflower cake }(\%)^{11}}^{11}$} \\
\cline { 2 - 6 } & 0 & 25 & 50 & 75 & 100 \\
\hline Tifton 85 hay $\left(\mathrm{g} \mathrm{kg}^{-1} \mathrm{DM}\right)$ & 400.00 & 400.00 & 400.00 & 400.00 & 400.00 \\
Ground corn $\left(\mathrm{g} \mathrm{kg}^{-1} \mathrm{DM}\right)$ & 483.76 & 467.33 & 444.00 & 408.00 & 348.19 \\
Soybean meal $\left(\mathrm{g} \mathrm{kg}^{-1} \mathrm{DM}\right)$ & 96.24 & 84.60 & 68.00 & 42.50 & 0.00 \\
Sunflower cake $\left(\mathrm{g} \mathrm{kg}^{-1} \mathrm{DM}\right)$ & 0.00 & 28.07 & 68.00 & 129.50 & 231.81 \\
Mineral and vitaminic mixture $\left(\mathrm{g} \mathrm{kg}^{-1} \mathrm{DM}\right)$ & 20.00 & 20.00 & 20.00 & 20.00 & 20.00 \\
\hline Total & 1000.00 & 1000.00 & 1000.00 & 1000.00 & 1000.00 \\
\hline $\mathrm{Chemical} \mathrm{composition}^{1}$ & & & & \\
$\mathrm{DM}^{1}\left(\mathrm{~g} \mathrm{~kg}^{-1}\right)$ & 824.26 & 825.29 & 826.75 & 829.00 & 832.75 \\
$\mathrm{OM}^{2}\left(\mathrm{~g} \mathrm{~kg}^{-1} \mathrm{DM}\right)$ & 940.83 & 940.30 & 939.54 & 938.38 & 936.44 \\
$\mathrm{CP}^{3}\left(\mathrm{~g} \mathrm{~kg}^{-1} \mathrm{DM}\right)$ & 126.80 & 126.81 & 126.80 & 126.82 & 126.83 \\
$\mathrm{EE}^{4}\left(\mathrm{~g} \mathrm{~kg}^{-1} \mathrm{DM}\right)$ & 23.69 & 28.70 & 35.82 & 46.80 & 65.06 \\
$\mathrm{NDF}^{5}\left(\mathrm{~g} \mathrm{~kg}^{-1} \mathrm{DM}\right)$ & 447.31 & 448.70 & 450.68 & 453.73 & 458.80 \\
$\mathrm{ADF}^{6}\left(\mathrm{~g} \mathrm{~kg}^{-1} \mathrm{DM}\right)$ & 160.30 & 164.34 & 170.09 & 178.94 & 193.66 \\
$\mathrm{CEL}^{7}\left(\mathrm{~g} \mathrm{~kg}^{-1} \mathrm{DM}\right)$ & 144.63 & 147.80 & 152.29 & 159.23 & 170.75 \\
$\mathrm{LIG}^{8}\left(\mathrm{~g} \mathrm{~kg}^{-1} \mathrm{DM}\right)$ & 135.75 & 138.85 & 143.25 & 150.04 & 161.32 \\
$\mathrm{TC}^{9}\left(\mathrm{~g} \mathrm{~kg}^{-1} \mathrm{DM}\right)$ & 790.34 & 784.79 & 776.92 & 764.75 & 744.56 \\
$\mathrm{NFC}^{10}\left(\mathrm{~g} \mathrm{~kg}^{-1} \mathrm{DM}\right)$ & 343.03 & 336.09 & 326.23 & 311.03 & 285.76 \\
\hline
\end{tabular}

${ }^{1}$ dry matter; ${ }^{2}$ organic matter; ${ }^{3}$ crude protein; ${ }^{4}$ ether extract; ${ }^{5}$ neutral detergent fiber; ${ }^{6}$ acid detergent fiber; ${ }^{7}$ cellulose; ${ }^{8}$ lignin; ${ }^{9}$ total carbohydrates; ${ }^{10}$ non-fiber carbohydrates. ${ }^{11} 0,25,50,75,100$, respectively, replacement levels of soybean meal by sunflower cake in diets

Source: Elaboration of the authors.

The direct method was used to determine the apparent digestibility of nutrients by evaluating the nutrient content in feed samples and feces. The apparent digestibility (AD) was obtained using the equation described by Coelho da Silva and Leão
(1979): $\mathrm{AD}=((\mathrm{Nf}-\mathrm{No}-\mathrm{Nfc}) /(\mathrm{Nf}-\mathrm{No}))^{*} 100$, where $\mathrm{Nf}=$ nutrient in feed $(\mathrm{g}), \mathrm{No}=$ nutrient in orts $(\mathrm{g})$, and $\mathrm{Nfc}=$ nutrient in feces $(\mathrm{g})$.

For urine collection, $25 \mathrm{~mL}$ of $1: 1 \mathrm{HCl}$ was placed in the collection containers daily between 
11 and 14 days in each experimental period to prevent fermentation and ammonia losses in the urine by volatilization The total volume of urine excreted per animal was measured at intervals of 24 hours, and an aliquot corresponding to $10 \%$ of the total volume per animal was stored at $-15^{\circ} \mathrm{C}$ for later composition analysis. Nitrogen balance was calculated as the difference between the total nitrogen intake and the total nitrogen excreted in feces and urine (DECANDIA et al., 2000), which were expressed in $\mathrm{g} \mathrm{day}^{-1}, \mathrm{~g} \mathrm{~kg} \mathrm{BW}^{-0.75}$ and $\mathrm{g} \mathrm{kg}^{-1}$ of $\mathrm{N}$ intake, respectively.

The total digestible nutrient (TDN) content of feedstuffs and diets were estimated according to the equation described by Sniffen, O'Condor and Van Soest (1992): $\mathrm{TDN}=\mathrm{DCP}+2.25 \mathrm{DEE}+\mathrm{DTCH}$, where: $\mathrm{DCP}=$ digestible crude protein, $\mathrm{DEE}=$ digestible ether extract, and DTCH = digestible total carbohydrates.

The rumen fluid was collected on the last day (15th day) of each experimental period before the morning feeding and at three and six hours after the morning feeding (ZEOULA et al., 2003) using an esophageal silicone probe connected to a vacuum pump. Approximately $100 \mathrm{~mL}$ of rumen fluid were collected from each animal. The $\mathrm{pH}$ was measured immediately after collection using a digital potentiometer. Afterwards, samples were filtered through three layers of cheesecloth, and three aliquots of $20 \mathrm{~mL}$ were taken from each sample. These samples were packed in pots containing sixteen drops of sulfuric acid $(50 \% \mathrm{~V} / \mathrm{V})$ and were stored at $-18^{\circ} \mathrm{C}$ for determination of the ruminal ammonia concentration $\left(\mathrm{NH}_{3}-\mathrm{N}\right) \cdot \mathrm{NH}_{3}-\mathrm{N}$ concentrations in the rumen fluid samples were determined by distillation with potassium hydroxide (2N), according to a technique described by Preston (1995). The color, odor and viscosity of the rumen fluid were observed immediately after collection according to the characteristics described by Bouda, Queiroz-Rocha and González (2000).

The experimental design was a Latin square design ( $5 \times$ x 5$)$ with five levels of residual frying oil, five periods of sampling and five animals (experimental units). However, for data relating to ruminal parameters $\left(\mathrm{pH}\right.$ and $\left.\mathrm{NH}_{3}-\mathrm{N}\right)$, the experimental design was a Latin square $(5 \times 5)$ in a parcel-subdivided scheme with levels of residual oil in the parcel and the collecting times in the subparcel. Data were submitted to a normality test for distribution of errors, to a homogeneity of variance test, and subsequently, to an analysis of variance $(\alpha=0.05)$. The statistical package R (2013) was used to study the mean values by regression analysis, using " $\mathrm{t}$ " test $(\alpha=0.05)$.

\section{Results and Discussion}

No differences were observed $(\mathrm{P}>0.05)$ in intake of dry matter (DM), organic matter (OM), crude protein (CP), neutral detergent fiber (NDF) and total digestible nutrients (TDN), regardless of the form expressed as shown in Table 3. This is due to the fact that the experimental diets have in their composition very close values of these nutritional components (Table 2), size of similar particles, and digestibility of these nutritional components in very similar on ration (Table 4), in order not to limit the intake of nutrients.

This result is satisfactory because evidence in experimental conditions imposed that the sunflower cake has no limiting intake, with good acceptability by the animals. Allied to the fact that it can completely replace the concentrated mixture a conventional food by another of lower commercial value and has the additional advantage of being a food with a higher energy density than soybean meal, due to a higher amount of ether extract in its composition (Table 1).

Similar results to those found in this study were verified by Souza Junior et al. (2011) evaluated the intake of fiber fractions of coconut cake in sheep feeding. Found no differences in DM, CP, working with animals with similar mean weight reported in 
this study. Pereira et al. (2011b) evaluated diets for find differences in the DM, OM, CP, confirming lactating cows with sunflower cake levels, did not results found in this study.

Table 3. Intake of nutrients in diets for lambs with different levels replacement of soybean meal by sunflower cake.

\begin{tabular}{|c|c|c|c|c|c|c|c|c|c|}
\hline \multirow{2}{*}{ Components } & \multicolumn{5}{|c|}{ Levels of sunflower cake $(\%)$} & \multirow{2}{*}{ Regression } & \multirow{2}{*}{$\mathrm{R}^{2}$} & \multirow{2}{*}{ P-value } & \multirow{2}{*}{$\begin{array}{l}\text { V.C } \\
(\%)\end{array}$} \\
\hline & 0 & 25 & 50 & 75 & 100 & & & & \\
\hline \multicolumn{10}{|c|}{ Intake $\mathrm{g}_{\text {animal }}{ }^{-1}$ day $^{-1}$} \\
\hline $\mathrm{DM}^{3}$ & 1305.8 & 1346.7 & 1381.0 & 1362.0 & 1346.8 & $\hat{\mathrm{Y}}=1348.5$ & - & ns & 3.94 \\
\hline $\mathrm{OM}^{4}$ & 1510.1 & 1548.6 & 1576.0 & 1549.7 & 1519.7 & $\hat{Y}=1540.8$ & - & $\mathrm{ns}$ & 3.07 \\
\hline $\mathrm{CP}^{5}$ & 215.9 & 220.1 & 222.2 & 219.6 & 217.0 & $\hat{Y}=219.0$ & - & $\mathrm{ns}$ & 1.89 \\
\hline $\mathrm{EE}^{6}$ & 40.5 & 48.8 & 61.8 & 81.0 & 112.1 & $\hat{Y}=33.78+0.70 x$ & 0.93 & $* *$ & 4.56 \\
\hline $\mathrm{NDF}^{7}$ & 659.5 & 684.1 & 708.3 & 696.9 & 712.3 & $\hat{\mathrm{Y}}=692.2$ & - & $\mathrm{ns}$ & 4.84 \\
\hline $\mathrm{TC}^{8}$ & 1253.6 & 1279.7 & 1292.0 & 1249.1 & 1190.5 & $\mathrm{~B}$ & 0.98 & $*$ & 3.34 \\
\hline $\mathrm{NDF}^{9}$ & 648.8 & 648.7 & 634.9 & 600.3 & 521.0 & $\hat{Y}=671.56-1.22 x$ & 0.79 & $* *$ & 2.28 \\
\hline $\mathrm{TDN}^{10}$ & 752.7 & 744.3 & 784.7 & 820.6 & 888.5 & $\hat{Y}=798.2$ & - & $\mathrm{ns}$ & 11.97 \\
\hline \multicolumn{10}{|c|}{ Intake $\%$ body weight } \\
\hline $\mathrm{DM}^{3}$ & 37.1 & 38.30 & 38.9 & 38.5 & 38.40 & $\hat{\mathrm{Y}}=38.3$ & - & $\mathrm{ns}$ & 3.72 \\
\hline $\mathrm{OM}^{4}$ & 43.3 & 44.2 & 44.5 & 44.0 & 43.6 & $\hat{Y}=43.9$ & - & $\mathrm{ns}$ & 2.66 \\
\hline $\mathrm{CP}^{5}$ & 6.2 & 6.3 & 6.3 & 6.2 & 6.2 & $\hat{\mathrm{Y}}=6.2$ & - & ns & 1.67 \\
\hline $\mathrm{EE}^{6}$ & 1.2 & 1.4 & 1.7 & 2.3 & 3.2 & $\hat{\mathrm{Y}}=0.96+0.02 \mathrm{x}$ & 0.92 & $* *$ & 8.43 \\
\hline $\mathrm{NDF}^{7}$ & 19.0 & 19.5 & 20.0 & 19.7 & 20.5 & $\hat{Y}=19.8$ & - & $\mathrm{ns}$ & 4.08 \\
\hline $\mathrm{TC}^{8}$ & 36.0 & 36.5 & 36.5 & 35.4 & 34.1 & $\hat{Y}=36.6-0.0189 x$ & 0.57 & $*$ & 2.94 \\
\hline $\mathrm{NDF}^{9}$ & 18.5 & 18.5 & 18.0 & 17.1 & 14.9 & $\hat{Y}=19.13-0.035 x$ & 0.82 & $* *$ & 2.98 \\
\hline $\mathrm{TDN}^{10}$ & 21.6 & 21.2 & 22.1 & 23.2 & 25.6 & $\hat{\mathrm{Y}}=22.8$ & - & $\mathrm{ns}$ & 11.13 \\
\hline \multicolumn{10}{|c|}{ Intake $\mathrm{g} \mathrm{kg}^{-1}$ body weight ${ }^{0.75}$} \\
\hline $\mathrm{DM}^{3}$ & 90.2 & 93.1 & 94.9 & 93.8 & 93.4 & $\hat{Y}=93.1$ & - & ns & 3.80 \\
\hline $\mathrm{OM}^{4}$ & 105.0 & 107.3 & 108.6 & 107.0 & 105.7 & $\hat{Y}=106.7$ & - & $\mathrm{ns}$ & 2.76 \\
\hline $\mathrm{CP}^{5}$ & 15.0 & 15.3 & 15.3 & 15.2 & 15.1 & $\hat{Y}=15.2$ & - & $\mathrm{ns}$ & 1.69 \\
\hline $\mathrm{EE}^{6}$ & 2.8 & 3.4 & 4.2 & 5.6 & 7.8 & $\hat{\mathrm{Y}}=2.34+0.0487 \mathrm{x}$ & 0.93 & $* *$ & 7.01 \\
\hline $\mathrm{NDF}^{7}$ & 46.0 & 47.5 & 48.8 & 48.1 & 49.7 & $\hat{\mathrm{Y}}=48.0$ & - & $\mathrm{ns}$ & 4.26 \\
\hline $\mathrm{TC}^{8}$ & 87.2 & 88.7 & 89.0 & 86.3 & 82.8 & $\hat{Y}=89.03-0.045 x$ & 0.50 & $*$ & 3.03 \\
\hline $\mathrm{NDF}^{9}$ & 45.0 & 44.9 & 43.8 & 41.5 & 36.1 & $\hat{Y}=46.48-0.0846 x$ & 0.81 & $* *$ & 2.72 \\
\hline $\mathrm{TDN}^{10}$ & 52.4 & 51.6 & 53.9 & 56.6 & 62.0 & $\hat{\mathrm{Y}}=55.3$ & - & $\mathrm{ns}$ & 11.39 \\
\hline
\end{tabular}

${ }^{11} 0,25,50,75,100$, respectively, replacement levels of soybean meal by sunflower cake in diets; ${ }^{2}$ variation coefficient; ${ }^{3} \mathrm{dry}$ matter ${ }^{4}$ organic matter; ${ }^{5}$ crude protein; ${ }^{6}$ ether extract; ${ }^{7}$ neutral detergent fiber; ${ }^{8}$ total carbohydrates; ${ }^{9}$ non-fiber carbohydrates; ${ }^{10}$ total digestible nutrients; ${ }^{\mathrm{B}} \hat{\mathrm{Y}}=1252.3+1.9385 \mathrm{x}-0.0257 \mathrm{x}^{2}$ (Maximmum point $=37.71 \%$ of replacement of soybean meal by sunflower cake); ns= non significat; ${ }^{*},{ }^{*}$ significant at 5 and $1 \%$ for "t test", respectively

Source: Elaboration of the authors.

Experimental diets containing levels sunflower cake were able to meet the nutritional demands without limiting nutrient intake. The results were consistent with the recommendations by the NRC (2007), which proposes values of $900 \mathrm{~g} \mathrm{day}^{-1}$ or
$3.0 \%$ of body weight to the DM, and $141 \mathrm{~g} \mathrm{day}^{-1}$ to CP intake and $720 \mathrm{~g} \mathrm{day}^{-1}$ to TDN intake to lambs with $30 \mathrm{~kg}$ of weight, aged 8 months.

There was effect $(\mathrm{P}<0.05)$ linear increasing intake of ether extract (EE) independent expressly, 
a fact due to the higher lipid content in sunflower cake compared to soybean meal (Table 1), which caused increase in content of this component in the rations (Table 2). Similar results on EE intake are found in the literature when oil cakes were used in diets for sheep (AGY et al., 2012; BOSSA et al., 2012). The increase in EE intake could indicate reduction in dry matter intake, however, this result was not observed, even in the diet with higher soybean cake which exceeded the critical limit (5\% EE in the feed) suggested by Palmquist and Mattos (2006). According to Allen (2000), the mechanisms by which lipid reduce intake depend on the physical form and chemical properties of lipid sources, and involve effects on rumen fermentation in the intestinal motility, the palatability of these diets on release intestinal hormones and fat oxidation in the liver.

For the intake of total carbohydrates (TC) and non-fiber carbohydrates (NFC) was observed linear decrease independent of the express way. Except for the CT intake that showed quadratic effect when expressed in $\mathrm{g} \mathrm{day}^{-1}$ (Table 3 ) with maximum point of $37.71 \%$ of sunflower cake for soybean meal replacement. In this study, the reduction in the TC and NFC intake are probably due to the reduction of the levels of these fractions in the diets, which in turn is directly related to EE increased in diets with higher levels of sunflower cake. The interference of $\mathrm{EE}$ on the contents of TC is because the $\mathrm{EE}$ is one of the components that compose the calculation to determine the CT. Azevedo et al. (2012) also had differences in intake of EE and NFC when studied macauba cake in feeding lambs.

Probably not change $(\mathrm{P}>0.05)$ of $\mathrm{DM}, \mathrm{OM}, \mathrm{CP}$, NDF (Table 4), was due to the stability on intake of these components to replace soybean meal by sunflower cake, this fact suggest that the protein sunflower cake can be comparable protein soybean meal when assessed by digestibility.

Table 4. Digestibility coefficient (\%) of diets according to the levels of replacement of soybean meal by sunflower cake.

\begin{tabular}{|c|c|c|c|c|c|c|c|c|c|}
\hline \multirow{2}{*}{ Components } & \multicolumn{5}{|c|}{ Levels of sunflower cake $(\%)^{1}$} & \multirow{2}{*}{ Regression } & \multirow{2}{*}{$\mathrm{R}^{2}$} & \multirow{2}{*}{ P-value } & \multirow{2}{*}{$\begin{array}{l}\text { V.C. }{ }^{2} \\
(\%)\end{array}$} \\
\hline & 0 & 25 & 50 & 75 & 100 & & & & \\
\hline $\mathrm{DM}^{3}$ & 79.3 & 78.3 & 78.1 & 78.0 & 79.1 & $\hat{\mathrm{Y}}=78.6$ & - & ns & 2.05 \\
\hline $\mathrm{OM}^{4}$ & 48.2 & 45.7 & 46.5 & 48.3 & 51.7 & $\hat{\mathrm{Y}}=48.1$ & - & ns & 11.11 \\
\hline $\mathrm{CP}^{5}$ & 36.5 & 32.5 & 33.8 & 36.4 & 42.3 & $\hat{\mathrm{Y}}=36.3$ & - & ns & 19.71 \\
\hline $\mathrm{EE}^{6}$ & 47.6 & 58.5 & 65.4 & 71.4 & 74.1 & $\hat{\mathrm{Y}}=50.21+0.26 \mathrm{x}$ & 0.95 & ** & 12.51 \\
\hline $\mathrm{NDF}^{7}$ & 26.2 & 18.0 & 23.0 & 25.2 & 35.0 & $\hat{\mathrm{Y}}=25.5$ & - & ns & 38.85 \\
\hline $\mathrm{TC}^{8}$ & 50.1 & 47.4 & 47.8 & 48.9 & 51.2 & $\hat{Y}=49.1$ & - & ns & 10.59 \\
\hline $\mathrm{NDF}^{9}$ & 78.8 & 82.6 & 79.1 & 80.4 & 77.3 & $\hat{\mathrm{Y}}=79.6$ & - & ns & 7.19 \\
\hline
\end{tabular}

${ }^{1} 0,25,50,75,100$, respectively, replacement levels of soybean meal by soybean cake in diets; ${ }^{2}$ variation coefficient; ${ }^{3} \mathrm{dry}$ matter ${ }^{4}$ organic matter; ${ }^{5}$ crude protein; ${ }^{6}$ ether extract; ${ }^{7}$ neutral detergent fiber; ${ }^{8}$ total carbohydrates; ${ }^{9}$ non-fiber carbohydrates; ns $=$ non significat; **significant at $1 \%$ for "t test"

Source: Elaboration of the authors.

The EE digestibility coefficient increased linearly with the replacement of soybean meal by sunflower cake (Table 4). Probably, increased EE digestibility in the present study, is due to the increase in the percentage of EE diets with the inclusion of sunflower cake, and the probable increase in digest retention time of this component digestion benefiting the digestion of lipidic source. Improvements in digestibility shows that the lipid fraction of sunflower cake is highly digestible. In addition, diets low in lipids, such as diet without addition of pie, the apparent digestibility values 
may be overestimated for the biosynthesis of lipids by microorganisms in the rumen and cecum (PALMQUIST; CONRAD, 1978).

Intake, fecal, urinary and retained nitrogen were not affected $(\mathrm{P}>0.05)$ by replacement levels of soybean meal by sunflower cake in the diets (Table 5). The forage: concentrate ratio, as well as the proteic source did not affect DM intake between evaluated diets (Table 3), thus the nitrogen intake, remained at around $35.0 \mathrm{~g}^{-}$day $^{-}$ ${ }^{1}$ per animal. There was no NB negative for any of the evaluated treatments, which indicates that the protein intake met the protein requirements of animals. The nitrogen retention from the absorbed nitrogen reflects the utilization of nitrogen in protein synthesis, to form new tissue, new enzyme systems or replace old tissue or epithelium. The efficiency with which this mechanism is performed primarily depends on composition nitrogen compound which reaches tissue, coming from intestinal absorption (EZEQUIEL et al., 2000). However, the amount of nitrogen retained in the body was lower as compared with the amount of nitrogen excreted via feces and urine with higher loss $\mathrm{N}_{\text {fecal }}$ compared $\mathrm{N}_{\text {urine }}$. According to Kozloski (2002), the amount of nitrogen excreted in feces increases with fermentation activity in the large intestine due to the increased microbial nitrogen supply source in the feces.

Table 5. Mean for intake, excretion and nitrogen of lambs fed diets with different levels of replacement at soybean meal by sunflower cake.

\begin{tabular}{|c|c|c|c|c|c|c|c|c|}
\hline \multirow{2}{*}{ Variable } & \multicolumn{5}{|c|}{ Levels of sunflower cake $(\%)^{1}$} & \multirow{2}{*}{ Mean } & \multirow{2}{*}{ P-value } & \multirow{2}{*}{$\begin{array}{l}\text { V.C. }{ }^{2} \\
(\%)\end{array}$} \\
\hline & 0 & 25 & 50 & 75 & 100 & & & \\
\hline \multicolumn{9}{|c|}{ Nitrogen intake } \\
\hline $\mathrm{g} \mathrm{day}^{-1}$ & 34.5 & 35.2 & 35.5 & 35.1 & 34.7 & 35.0 & $\mathrm{~ns}$ & 1.89 \\
\hline \multicolumn{9}{|c|}{ Nitrogen fecal } \\
\hline $\mathrm{g}$ day $^{-1}$ & 21.9 & 23.8 & 23.6 & 22.4 & 20.1 & 22.3 & $\mathrm{~ns}$ & 10.83 \\
\hline $\mathrm{g} \mathrm{kg}^{-1} \mathrm{~N}_{\text {intake }}$ & 635.0 & 675.0 & 662.0 & 636.0 & 576.0 & 637.0 & $\mathrm{~ns}$ & 11.23 \\
\hline \multicolumn{9}{|c|}{ Nitrogen urine } \\
\hline $\mathrm{g} \mathrm{day}^{-1}$ & 8.4 & 7.6 & 6.3 & 7.7 & 7.3 & 7.5 & ns & 21.81 \\
\hline $\mathrm{g} \mathrm{kg}^{-1} \mathrm{~N}_{\text {intake }}$ & 244.0 & 217.0 & 176.0 & 220.0 & 214.0 & 214.0 & $\mathrm{~ns}$ & 21.91 \\
\hline \multicolumn{9}{|c|}{ Nitrogen balance } \\
\hline $\mathrm{g} \mathrm{day}^{-1}$ & 4.3 & 3.8 & 5.7 & 5.0 & 7.3 & 5.2 & $\mathrm{~ns}$ & 56.19 \\
\hline $\mathrm{g} \mathrm{kg}^{-1} \mathrm{~N}_{\text {intake }}$ & 121.0 & 107.0 & 161.0 & 144.0 & 210.0 & 149.0 & $\mathrm{~ns}$ & 56.57 \\
\hline
\end{tabular}

${ }^{1} 0,25,50,75,100$, respectively, replacement levels of soybean meal by sunflower cake in diets; ${ }^{2}$ variation coefficient.; ns $=$ non significat

Source: Elaboration of the authors.

Through the evaluation of qualitative parameters of the rumen fluid in all treatments was observed dark brown and slightly viscous green color of the liquid and classified as aromatic odor, this fact can be inferred that the normality of the liquid was maintained due to production of volatile compounds generated in physiologically ruminal fermentation (Table 6).
There was no difference $(\mathrm{P}>0.05)$ for the reductive activity of methylene blue (Table 6). According Radostits et al. (2002), in the case of very active digestion occurs discoloration of methylene blue in 180 seconds. In the present study, the reduction occurred before 120 seconds for all treatments. Possibly the forage to concentrate ratio used (40:60), provided high ruminal activity. 
The observed the ruminal fluid $\mathrm{pH}$ values did not differ $(\mathrm{P}>0.05)$ for different substitution levels of soybean meal by sunflower cake (Table 6). However, the ruminal $\mathrm{pH}$ differed $(\mathrm{P}<0.05)$ compared to the collection time, for all experimental diets. Similar results $\mathrm{pH}$ (6.3 to 7.1) were verified by Zeoula et al. (2003). The ruminal $\mathrm{pH}$, in this study, is the ideal $\mathrm{pH}$ range between 5.5 and 7.0 (FURLAN; MACARI; FARIA FILHO, 2006). The ruminal $\mathrm{pH}$ can be varied according to diet and with time after feeding (SILVEIRA et al.; 2006).
Probably the high ruminal $\mathrm{pH}$ checked before feeding is related to the low amount of nutrients available to the rumen microbial metabolism and rumination activity of animals. According to Orskov (1988) values above $6.2 \mathrm{pH}$ of the ruminal fluid is considered as a minimum limit for adequate fermentation of the fiber. Maintaining adequate levels of $\mathrm{pH}$ buffering agents depends on the production capacity as the carbonate-based salts, and removal of VFA absorption through the rumen (VAN SOEST, 1982).

Table 6. Proportions of the predominant physical aspects, reduction time of methylene blue, $\mathrm{pH}$ and ammonia (NH3-N) in the time of collection and levels replacement soybean meal by sunflower cake in diets for lambs.

\begin{tabular}{|c|c|c|c|c|c|c|}
\hline \multirow{2}{*}{ Variables } & \multicolumn{5}{|c|}{ Levels of sunflower cake $(\%)^{*}$} & \multirow{2}{*}{ Mean } \\
\hline & 0 & 25 & 50 & 75 & 100 & \\
\hline \multicolumn{7}{|c|}{ Cor } \\
\hline Brownish dark green & 0.80 & 0.80 & 0.73 & 0.73 & 0.60 & \\
\hline Yellowish light green & 0.20 & 0.20 & 0.27 & 0.27 & 0.40 & \\
\hline Total & 1.00 & 1.00 & 1.00 & 1.00 & 1.00 & \\
\hline \multicolumn{7}{|c|}{ Smell } \\
\hline Aromatic & 1.00 & 0.93 & 1.00 & 0.87 & 1.00 & \\
\hline Sour & 0.00 & 0.07 & 0.00 & 0.13 & 0.00 & \\
\hline Total & 1.00 & 1.00 & 1.00 & 1.00 & 1.00 & \\
\hline \multicolumn{7}{|c|}{ Viscosity } \\
\hline Slightly viscous & 0.60 & 0.60 & 0.60 & 0.60 & 0.67 & \\
\hline Viscous & 0.40 & 0.40 & 0.40 & 0.40 & 0.33 & \\
\hline Total & 1.00 & 1.00 & 1.00 & 1.00 & 1.00 & \\
\hline \multicolumn{7}{|c|}{ Reduction time of methylene blue (seconds) } \\
\hline Before fedding & 108 & 120 & 96 & 108 & 108 & 108 \\
\hline $3 \mathrm{~h}$ after fedding & 84 & 96 & 84 & 84 & 72 & 84 \\
\hline $6 \mathrm{~h}$ after fedding & 84 & 96 & 108 & 96 & 96 & 96 \\
\hline \multirow[t]{2}{*}{ Mean } & 92 & 104 & 96 & 96 & 92 & \\
\hline & & & $\mathrm{pH}$ & & & \\
\hline Before fedding & 7.03 & 7.01 & 6.94 & 7.08 & 6.94 & $7.00 \mathrm{a}$ \\
\hline $3 \mathrm{~h}$ after fedding & 6.71 & 6.73 & 6.51 & 6.61 & 6.55 & $6.62 \mathrm{~b}$ \\
\hline $6 \mathrm{~h}$ after fedding & 6.62 & 6.64 & 6.54 & 6.84 & 6.49 & $6.63 \mathrm{c}$ \\
\hline \multirow[t]{2}{*}{ Mean } & 6.79 & 6.79 & 6.67 & 6.84 & 6.66 & \\
\hline & \multicolumn{5}{|c|}{$\mathrm{NH}_{3}-\mathrm{N}$} & \\
\hline Before fedding & 30.75 & 30.75 & 32.56 & 31.64 & 33.10 & 31.76 \\
\hline $3 \mathrm{~h}$ after fedding & 31.83 & 29.09 & 31.19 & 29.99 & 32.33 & 30.89 \\
\hline $6 \mathrm{~h}$ after fedding & 27.26 & 27.45 & 32.12 & 32.48 & 32.33 & 30.33 \\
\hline Mean & 29.95 & 29.10 & 31.96 & 31.37 & 32.58 & \\
\hline
\end{tabular}

${ }^{*} 0,25,50,75,100$, respectively, replacement levels of soybean meal by sunflower cake in diets; same letters in columns do not differ by Tukey test $5 \%$.

Source: Elaboration of the authors. 
There was no effect $(\mathrm{P}>0.05)$ of collections time as well as diets containing sunflower cake on the $\mathrm{NH}_{3}-\mathrm{N}$ content (Table 6). The $\mathrm{NH}_{3}-\mathrm{N}$ concentrations in rumen fluid for the different diets were observed above the considered optimum (23.5 mg dL-1) by Mehrez, Ørskov and McDonald (1977), to obtain a position to achieve maximum microbial fermentation in ruminants. Santos et al. (2012) to evaluate diets with different byproducts oilseeds found average concentration of ammonia- $\mathrm{N}$ of $29.9 \mathrm{mg} \mathrm{dL}^{-1}$ rumen fluid, similar to results measured in this study. Van Soest (1994) reported that the nitrogen supply in the rumen microbial growth promoted to the extent the requirements of microorganisms. However, this requirement is related to the available fermentable carbohydrates in the production of ATP and the conversion efficiency in microbial cells. Thus, the sunflower cake are considered a feed protein, capable of providing nitrogen content in an amount adequate to maintain the development of rumen bacteria without compromising animal intake.

\section{Conclusion}

Concluded that the sunflower cake can be used as an alternative in the feed of soybean meal replacement, and can totally replace it in the concentrate or even $23.18 \%$ of the total feed mixture without the occurrence of changes in the intake and digestibility of the nutritional components, nitrogen balance and ruminal fermentation parameters.

\section{Acknowledgements}

The authors express sincere thanks CNPq for financing the research project.

This article was approved by the Ethics Commission on the use of animals at the Londrina State University, filed with this committee under number $60 / 10$, process number $123 / 2010$, this experiment was carried out in accordance with the technical standards of biosafety and ethics.

\section{References}

ABDAllA, A. L.; SILVA FILHO, J. C.; GODOI, A. R.; CARMO, C.A.; EDUARDO, J. L. P. Utilização de subprodutos da indústria de biodiesel na alimentação de ruminantes. Revista Brasileira de Zootecnia, Viçosa, v. 37, p. 260-258, 2008.

AGY, M. S. F. A.; OLIVEIRA, R. L.; RIBEIRO, C. V. M.; RIBEIRO, M. D.; BAGALDO, A. R.; ARAÚJO, G. G. L.; PINTO, L. F. B.; RIBEIRO, R. D. X. Sunflower cake from biodiesel production fed to crossbred Boer kids. Revista Brasileira de Zootecnia, Viçosa, v. 41, n. 1, p. 123-130, 2012.

ALLEN, M. S. Effects of diet on short-term regulation of feed intake by lactating dairy cattle. Journal of Dairy Science, Champaign, v. 83, n. 7, p. 1598-1624, 2000.

ASSOCIATION OF OFFICIAL ANALYTICAL CHEMISTS - AOAC. Official methods of analysis. 15. ed. Washington: AOAC, 1990.

AZEVEDO, R. A.; RUFINO, L. M. A.; SANTOS, A. C. R.; SILVA, L. P.; BONFÁ, H. C.; DUARTE, E. R.; CASTRO, L. G.; Desempenho de cordeiros alimentados com inclusão de torta de macaúba na dieta. Pesquisa Agropecuária Brasileira, Brasília, v. 47, n. 11, p. 16631668, 2012.

BERAN, F. H. B.; SILVA, L. D. F.; RIBEIRO, E. L. A.; ROCHA, M. A.; EZEQUIEL, J. M. B.; CORREA, R. A.; CASTRO, V. S.; SILVA, K. C. F. Avaliação da digestibilidade de nutrientes, em bovinos, de alguns alimentos concentrados pela técnica de três estádios. Revista Brasileira de Zootecnia, Viçosa, v. 36, n. 1, p. 130-137, 2007.

BOSSA, R.; FATURI, C.; VASCONCELOS, H. G. R.; CARDOSO, A. M.; RAMOS, A. F. O.; AZEVEDO, J. C. Consumo e digestibilidade aparente de dietas com diferentes níveis de inclusão de torta de coco para alimentação de ovinos. Acta Scientiarum. Animal Sciences, Maringá, v. 34, n. 1, p. 57-62, 2012.

BOUDA, J.; QUEIROZ-ROCHA, G. F.; GONZÁLEZ, F. H. D. Importância da coleta e análise de líquido ruminal e urina. In: GONZÁLES, F. H. D.; BORGES, J. B.; CECIM, M. (Ed.). Uso de provas de campo e laboratório clínico em doenças metabólicas e ruminais dos bovinos, Porto Alegre: UFRGS, 2000. p. 13-15.

COELHO DA SILVA, J. F.; LEÃO, M. I. Fundamentos de nutrição dos ruminantes. Piracicaba: Editora Livroceres, 1979. $380 \mathrm{p}$.

DECANDIA, M.; SITZIA, M.; CABIDDU, A.; KABABYAB, D.; MOLLE, G. The use of polyethylene glycol to reduce the anti-nutritional effects of tannins 
in goat fed woody species. Small Ruminant Research, Amsterdam, v. 38, n. 2, p. 157-164, 2000.

DETMANN, E.; VALENTE, T. N. P.; BERCHIELLI, T. T. Avaliação de fibra insolúvel em detergente neutro e da fibra insolúvel em detergente ácido. In: DETMANN, E.; SOUSA, M. A.; VALADARES FILHO, S. C.; QUEIROZ, A. C.; BERCHIELLI, T. T.; SALIBA, E. O. S.; CABRAL, L. S.; PINA, D. S.; LADEIRA, M. M.; AZEVEDO, J. A. G. (Ed.). Métodos para análises de alimentos - Instituto Nacional de Ciência e Tecnologia de Ciência Animal. Visconde do Rio Branco: Suprema, 2012. p. 93-111.

EZEQUIEL, J. M. B.; SAMPAIO, A. A. M.; SEIXAS, J. R. C.; OLIVEIRA, M. M. Balanço de nitrogênio e digestão total da proteína e da energia de rações contendo farelo de algodão, levedura de cana-de-açúcar ou uréia, em ovinos. Revista Brasileira de Zootecnia, Viçosa, v. 29, n. 6, p. 2332-2337, 2000.

FURLAN, R. L.; MACARI, M.; FARIA FILHO, D. E. Anatomia e fisiologia do trato gastrintestinal. In: BERCHIELLI, T. T.; PIRES, A. V.; OLIVEIRA, S. G. Nutrição de ruminantes. Jaboticabal: Funep, 2006. p. 1-24.

GOES, R.H. T.; SOUZA, K. A.; PATUSSI, R. A.; CORNELIO, T. C.; OLIVEIRA, E. R.; BRABES, K. C. S. Degradabilidade in situ dos grãos de cambre, girassol e soja, e de seus coprodutos em ovinos. Acta Scientiarum. Animal Sciences, Maringá, v. 32, n. 3, p. 271-277, 2010.

KOZLOSKI, G. V. Bioquímica dos ruminantes. Santa Maria: Universidade Federal de Santa Maria, 2002. 140 p.

LAGE, J. F.; PAULINO, P. V. R.; PEREIRA, L. G. R.; VALADARES FILHO, S. C.; OLIVEIRA, A. S.; DETMANN, E.; SOUZA, N. K. P.; LIMA, J. C. M. Glicerina bruta na dieta de cordeiros terminados em confinamento. Pesquisa Agropecuária Brasileira, Brasília, v. 45, n. 9, p. 1012-1020, 2010.

MEHREZ, A. Z.; ØRSKOV, E. R.; McDONALD, I. Rate of rumen fermentation in relation to ammonia concentration. Brittish Journal of Nutrition, Cambridge, v. 38, n. 3, p. 437-443, 1977.

MIZUBUTI, I. Y.; PINTO, A. P.; PEREIRA, E. S.; RAMOS, B. M. O. Métodos laboratoriais de avaliação de alimentos para animais. Londrina: EDUEL, 2009, v. $1.228 \mathrm{p}$.

NAGALAKSHMI, D.; DHANALAKSHMI, K.; HIMABINDU, D. Replacement of groundnut cake with sunflower and karanj seed cakes on performance, nutrient utilisation, immune response and carcass characteristics in Nellore lambs. Small Ruminant Research, Amsterdam v. 97, n. 2, p. 12-20, 2011.
NATIONAL RESEARCH COUNCIL - NRC. Nutrient requirements of small ruminants: sheep, goats, cervids and new world camelids. National Academy Press: Washington, DC, 2007. 384 p.

ORSKOV, E. R. Nutrición proteica de los rumiantes. Zaragoza: Acribia, 1988. 178 p.

PALMQUIST, D. L.; CONRAD, R. High fat rations for dairy cows. Effects on feed intake, milk and fat production, and plasma metabolites. Journal of Dairy Science, Champaign, v. 61, n. 7, p. 890-901, 1978.

PALMQUIST, D. L.; MATTOS, W. R. S. Metabolismo de lipídeos. In: BERCHIELLI, T. T.; PIRES, A. V.; OLIVEIRA, S. G. (Ed.). Nutrição de ruminantes. Jaboticabal: FUNEP, 2006. p. 287-310.

PEREIRA, E. S.; PIMENTEL, P. G.; CARNEIRO, M. S. S.; MIZUBUTI, I. Y.; RIBEIRO, E. L. A.; ROCHA JUNIOR; J. N.; FERREIRA, M. R. G. Comportamento ingestivo de vacas em lactação alimentadas com rações a base de torta de girassol Costa. Semina: Ciências Agrárias, Londrina, v. 32, n. 3, p. 1201-1210, 2011 b.

PEREIRA, E. S.; PIMENTEL, P. G.; BOMFIM, M. A. D.; CARNEIRO, M. S. S.; CÂNDIDO, M. J. D. Torta de girassol em rações de vacas em lactação: produção microbiana, produção, composição e perfil de ácidos graxos do leite. Acta Scientiarum. Animal Sciences, Maringá v. 33, n. 4, p. 387-394, 2011 a.

PEREZ, E. E.; CARELLI, A. A.; CRAPISTE, H. G. Chemical characterization of Oliz and meals from wild sunflower (Helianthus petiolaris Nutt). Journal of the American Oil Chemists Society, Champaign, v. 81, n. 3, p. 245-249, 2004.

PRESTON, T. R. Biological and chemical analytical methods. In. (Ed.). Tropical animal feeding: a manual for research workers. Rome: FAO, 1995, p. 191264.

R DEVELOPMENT CORE TEAM. $R$ : a language and environment for statistical computing. Vienna: $\mathrm{R}$ Foundation for Statistical Computing, 2013. Available at: $<$ http://www.R-project.org>. Accessed at: 10 abr. 2013.

RADOSTITS, O. M.; GAY, C. C.; BLOOD, D. C.; HINCHCLIFF, K. W. Clínica veterinária. 9. ed. Rio de Janeiro: Guanabara Koogan, 2002. 1737 p.

SANTOS, V. C.; EZEQUIEL, J. M. B.; MORGADO, E. S.; HOMEM JÚNIOR, A. C.; FÁVARO, V. R.; D'AUREA, A. P.; SOUZA, J. C.; BARBOSA, J. C. Influence byproducts of oleaginous on ruminal parameters and degradation of dry matter and crude protein. Arquivo Brasileiro de Medicina Veterinária e Zootecnia, Belo Horizonte, v. 64, n. 5, p. 1284-1291, 2012. 
SILVEIRA, M. F.; KOZLOSKI, G. V.; BRONDANI, I. L.; ALVES FILHO, D. C.; RESTLE, J.; LEITE, D. T.; METZ, P. A. M.; SILVEIRA, S. R. L. Ganho de peso vivo e fermentação ruminal em novilhos mantidos em pastagem cultivada de clima temperado e recebendo diferentes suplementos. Ciência Rural, Santa Maria, v. 36, n. 3, p. 898-903, 2006.

SNIFFEN, C. J.; O'CONNOR, J. D.; VAN SOEST, P. J. A net carbohydrate and protein system for evaluating cattle diets: carbohydrate and protein availability. Journal of Animal Science, Madison, v. 70, n. 11, p. 3562-3577, 1992.

SOUZA JUNIOR, L.; LOURENÇO JÚNIOR, J. B.; SANTOS, N. F. A.; FERREIRA, G. D. G.; GARCIA, A. R.; NAHÚM, B. S. Ingestão de alimentos e digestibilidade aparente das frações fibrosas da torta de coco para ovinos. Acta Scientiarum. Animal Sciences. Maringá, v. 33, n. 2, p. 169-174, 2011.
VAN SOEST, P. J. Development of a comprehensive system of feed analysis and its application to forages. Journal of Animal Science, Madison, v. 26, n. 1, p. 119128, 1967.

. Nutritional ecology of ruminant. 2. ed. Ithaca: Cornell University, 1994. $476 \mathrm{p}$. 2. ed. Corvalis: O. \& B. Books, 1982.

ZEOULA, L. M.; CALDAS NETO, S. F.; GERON, L. J. V.; MAEDA, E. M.; PRADO, I. N.; DIAN, P. H. M.; JORGE, J. R. V.; MARQUES, J. A. Substituição do milho pela farinha de varredura de mandioca (Manihot esculent, Crantz) em rações de ovinos: consumo, digestibilidade, balanços de nitrogênio e energia e parâmetros ruminais. Revista Brasileira de Zootecnia, Viçosa, v. 32, n. 2, p. 491-502, 2003. 